\title{
Thermochronologic constraints on Jurassic rift flank denudation in the Thiel Mountains, Antarctica
}

\author{
P. G. Fitzgerald and S. L. Baldwin \\ Department of Earth Sciences, 204 Heroy, Syracuse University, Syracuse, NY 13244, USA (pgfitzge@syr.edu, sbaldwin@syr.edu)
}

\begin{abstract}
The Thiel Mountains are part of the Transantarctic Mountains (TAM) and occupy a strategic position close to the East-West Antarctic boundary. They occur in a region of relatively subdued topography distal from high topography and high relief of most of the TAM adjacent to the West Antarctic rift system. Low-temperature thermochronology on samples collected from the Reed Ridge granite on the north flank of the Thiel Mountains constrain the thermal and hence tectonic history. Apatite fission track data plus thermal models indicate cooling from ca. $165-150 \mathrm{Ma}$. In conjunction with ${ }^{40} \mathrm{Ar} /{ }^{39} \mathrm{Ar} \mathrm{K}$-feldspar data, the results indicate cooling was due to relatively slow erosional denudation, and not thermal relaxation following Jurassic tholeiitic magmatism. Denudation was most likely associated with the formation of the Jurassic rift system across Antarctica that marked the initial breakup of Gondwana. This is the oldest episode of denudation associated with formation of the present day TAM.
\end{abstract}

Citation: Fitzgerald, P.G. and S.L. Baldwin (2007), Thermochronologic constraints on Jurassic rift flank denudation in the Thiel Mountains, Antarctica, in Antarctica: A keystone in a Changing World - Online Proceedings of the 10th ISAES, edited by A. K. Cooper and C. R. Raymond et al., USGS Open-File Report 2007-1047, Short Research Paper 044, 4 p.; doi:10.3133/of2007-1047.srp044

\section{Introduction}

The $\sim 3500 \mathrm{~km}$ long Transantarctic Mountains (TAM) mark the physiographic and lithospheric divide between East and West Antarctica (Dalziel, 1992). The TAM bisect the continent and act as a geomorphic barrier for the East Antarctic Ice Sheet. The Thiel Mountains occur in a distal part of the TAM and lie on the TAM side of the prominent Ellsworth-Whitmore Mountains (EWM)-Thiel Mountains ridge (Craddock, 1983) that defines the sub-ice topographic divide between the Weddell and Ross Embayments (Fig. 1a). While the TAM include majestic peaks in parts of Victoria Land or the Central TAM, the topography becomes subdued away from the coast of the Ross Embayment (i.e., the boundary with the adjacent West Antarctic rift system). In the Thiel Mountains region, the TAM are no longer a more or less continuous range, broken only by outlet glaciers, but are an isolated range, emergent as a series of escarpments from under the East Antarctic Ice Sheet. Morphologically, the Thiel Mountains resembles a plateau, tilted gently to the west, with ca. $600 \mathrm{~m}$ of relief at the northern end of the range (Ford Massif). At the southern end of the range, the plateau edge is more dissected with $\sim 400$ m of relief.

The objective of this study was to apply thermochronology to samples collected from the Thiel Mountains to constrain their denudation history, and hence the formation of the present day TAM.

\section{Geology of the Thiel Mountains}

The Thiel Mountains occupy a strategic location as they crop out very close to the East-West Antarctic boundary. Elsewhere this boundary is between the TAM and the West Antarctic rift system, but in this part of Antarctica, the boundary lies between the dissected TAM and the EWM crustal block. Defined by different lithologies, the boundary lies either north or south of the Stewart Hills (Storey and Dalziel, 1987).

In the Thiel Mountains the most widespread rock type is the Thiel Mountains Porphyry, intruded by (or in places migmatitic with) the Reed Ridge Granite (Ford and Aaron, 1962; Pankhurst et al. 1988). R/Sr and U-Pb ages are $502 \pm 3$ and $500 \pm 4 \mathrm{Ma}$, respectively (Pankhurst et al. 1988; Van Schmus et al. 1997). The Mount Walcott

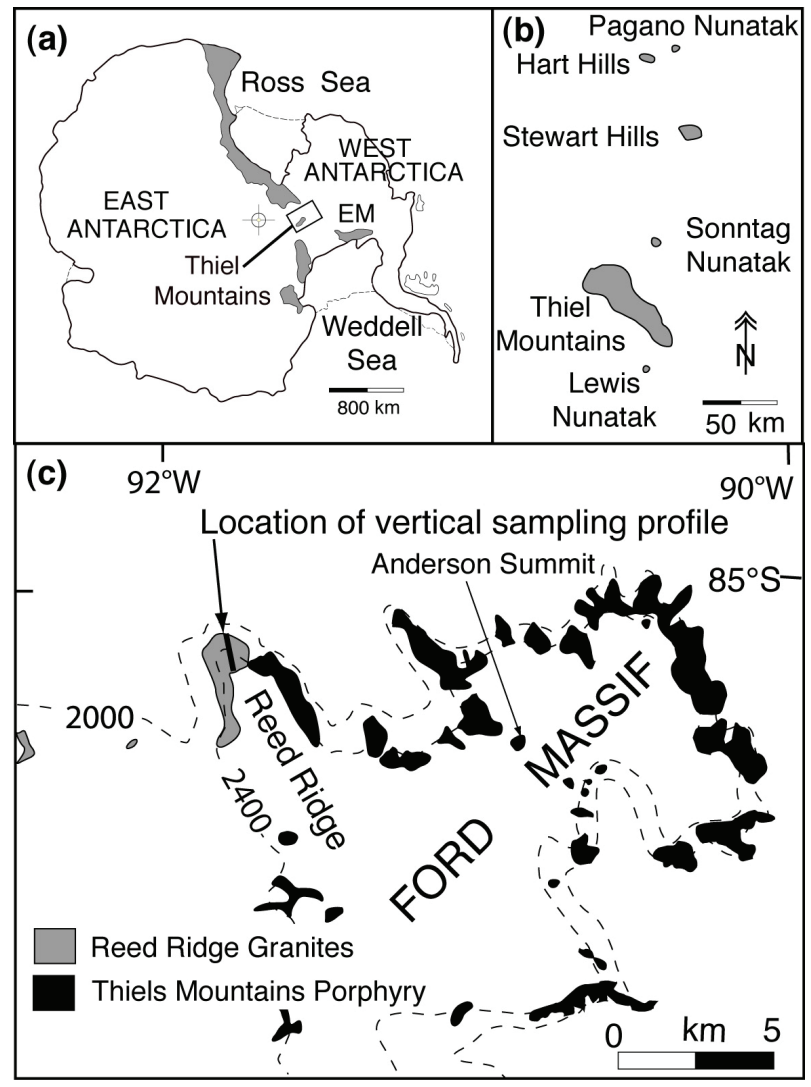

Figure 1. Location maps: (a) Thiel Mountains in Antarctica, EM = Ellsworth Mountains. (b) a regional context. (c) Geology and sampling profile on the Ford Massif (modified from Thiel Mountains USGS 1:250,000 scale map and Pankhurst et al., 1988). 
Formation, an interbedded shallow-marine sedimentary and volcanic sequence, in fault contact with porphyry, is also Cambro-Ordovician (Pankhurst et al., 1988). The mesa-like geomorphology of the Thiel Mountains (Ford and Aaron, 1962) is suggestive of an erosion surface on top of the range. However, neither the Kukri Peneplain, Jurassic Ferrar Dolerite sills or Beacon Supergroup sediments are present, not even on the highest point of the range (Anderson Summit, $2812 \mathrm{~m}$ ) that we climbed to look for Beacon sediments and/or Jurassic sills. However, Lewis Nunatak (Fig. 1b), 70 km SSW of the Ford Massif, is comprised of a massive Ferrar Dolerite sill with metamorphosed flat-lying metasediments at the base of this sill, likely part of the Beacon Supergroup (e.g., Story and Dalziel, 1987).
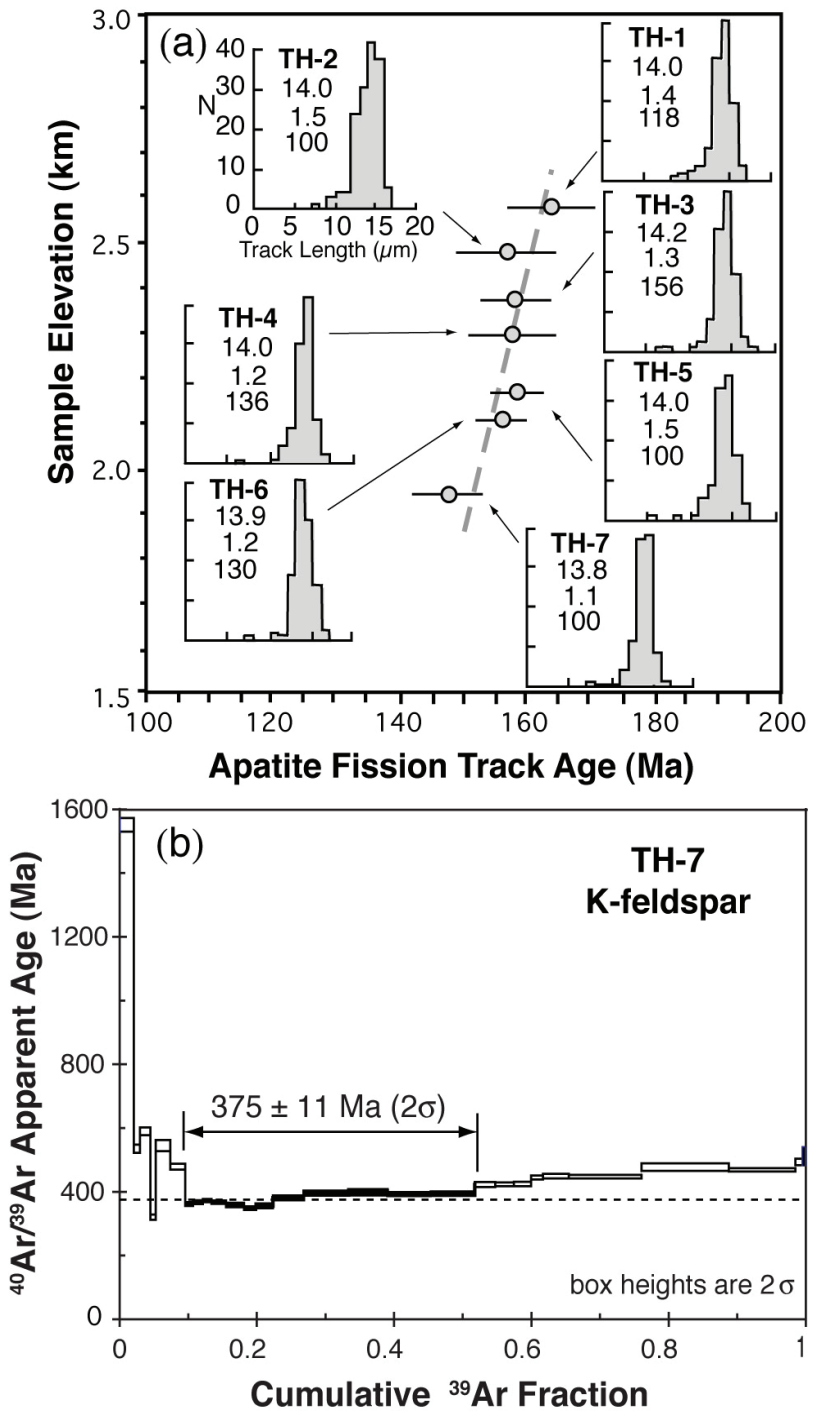

Figure 2. (a) AFT age vs. elevation plot plus confined track length distributions (showing sample number, mean length and standard deviation in microns, number of tracks measured) for the Reed Ridge vertical profile. (b) ${ }^{40} \mathrm{Ar} /{ }^{39} \mathrm{Ar}$ age spectra for feldspar from sample TH-7.

\section{Methods, results and discussion}

Apatite fission track (AFT) thermochronology on 7 samples collected over $>600 \mathrm{~m}$ of relief from Reed Ridge was performed using procedures outlined in Fitzgerald et al. (2006). AFT ages vary from 164 to $149 \mathrm{Ma}$ (Fig. 2), that combined with mean lengths (all $>13.8 \mu \mathrm{m}$ ) indicate cooling to below the base of the apatite partial annealing
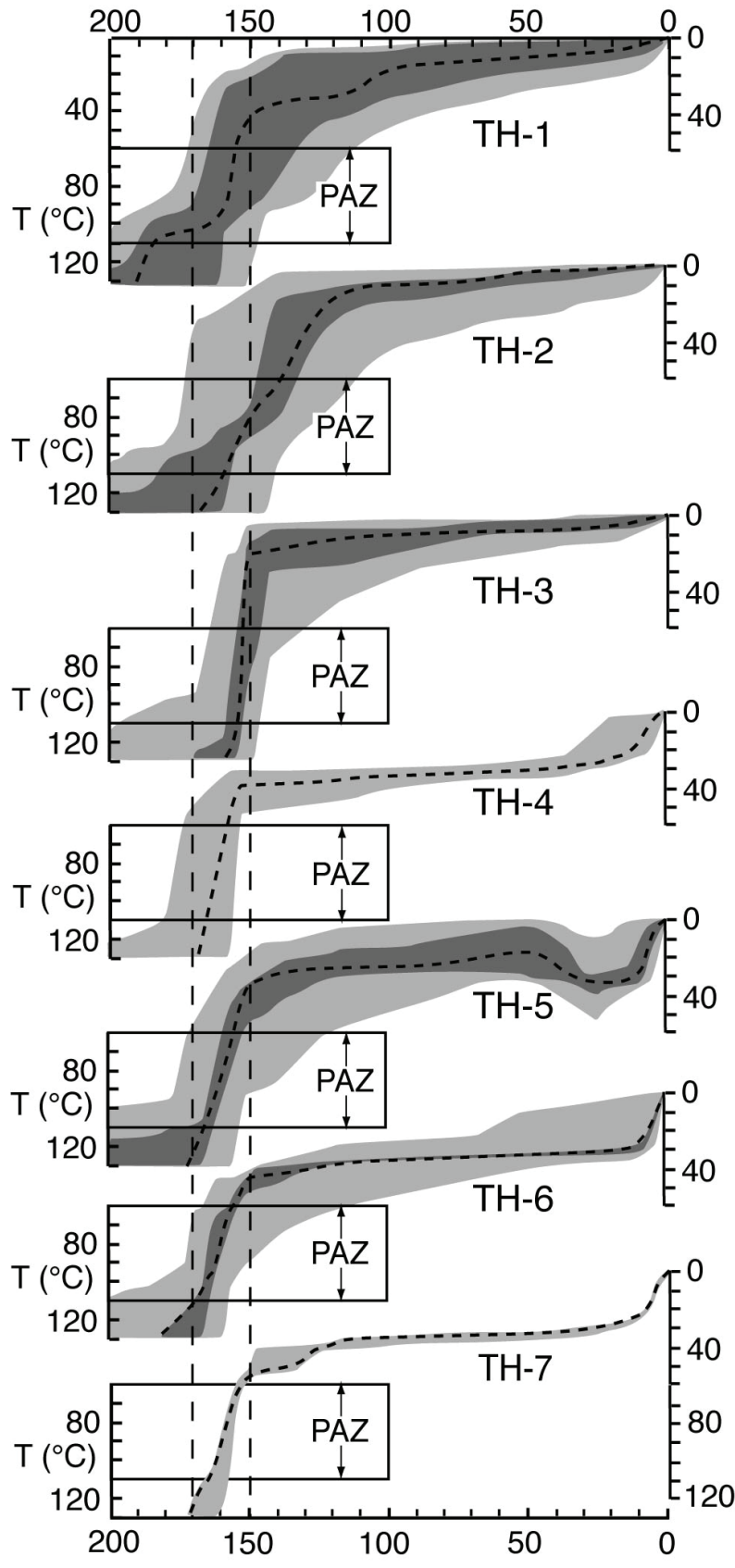

Figure 3. Time-temperature models for AFT data using AFTSolve (Ketcham et al., 2000) indicating cooling between $\sim 165-150 \mathrm{Ma}$. Dashed line is the "best fit", dark gray envelope is a good fit (the T-t path is supported by the data) and light gray envelope is an "acceptable fit" (T$t$ path is not ruled out by the data). 
zone (PAZ) by Late Jurassic. Qualitatively, there may be subtle indications in the AFT age/length vs. elevation plot suggesting a decrease in the cooling rate in the lowermost samples. Realistically, a robust interpretation is that relatively rapid cooling was ongoing in the Late Jurassic (ca. 165-150 Ma), but the onset of this cooling is not clearly revealed, for example by the presence of the base of an exhumed PAZ (Fitzgerald and Gleadow, 1990). Thermal modeling of track length distributions and ages (Fig. 3) indicates a cooling rate $<10^{\circ} \mathrm{C} / \mathrm{m}$.y., beginning ca. $165 \mathrm{Ma}$ and slowing ca. $150 \mathrm{Ma}$. These samples were resident at shallow crustal depths $(<$ ca. $4 \mathrm{~km})$ since ca. $150 \mathrm{Ma}$, but the data do not preclude other cooling episodes (e.g., in the Cretaceous or Cenozoic), as observed elsewhere along the TAM (e.g., Fitzgerald, 2002). However, evidence for later cooling episodes is not revealed in this data set.

Possible T-t paths (Fig. 4) for the cooling revealed in the AFT data include: [1] Thermal relaxation of isotherms following resetting of fission tracks in apatites due to a thermal pulse associated with Jurassic tholeiitic magmatism (e.g., Elliot, 1992). In this scenario, samples resided at relatively shallow levels in the crust $(<4 \mathrm{~km})$ prior to the Late Jurassic, before being reset due to thermal effects of the Jurassic magmatism followed by thermal relaxation of isotherms and cooling. [2] Cooling due to denudation. In this scenario, if samples were already at temperatures greater than temperatures at the base of the PAZ, they would already have a zero age, and later cooling through the PAZ would be due to denudation.

It is difficult to distinguish between these possibilities using the AFT data alone. To help resolve this, we undertook a ${ }^{40} \mathrm{Ar} /{ }^{39} \mathrm{Ar}$ step-heating experiment on $\mathrm{K}$ feldspar from the lowest elevation sample TH-7, the sample most likely to record a regional thermal event in the Jurassic. Ferrar magmatism occurred in a very short time interval ( $<1 \mathrm{m.y}$.) at ca. $180 \mathrm{Ma}$ (Encarnación et al., 1996; Fleming et al., 1997; Elliot and Fleming, 2004), and if the feldspar was reset due to the accompanying thermal effects, we would expect to see the effects of partial loss. Despite the first $\sim 10 \%$ of gas yielding high apparent ${ }^{40} \mathrm{Ar} /{ }^{39} \mathrm{Ar}$ ages, the form of the age spectra does not provide evidence that this sample was partially reset due to thermal effects of Jurassic magmatism. Unfortunately, partial sericitization of the K-feldspar precluded the use of

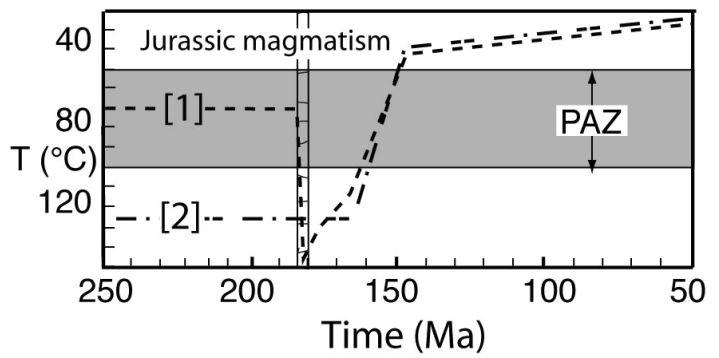

Figure 4. Possible T-t paths responsible for the cooling revealed in the AFT data. See text for discussion. multi-diffusion domain modeling on this sample, and hence derivation of a cooling curve from $\sim 300-150^{\circ} \mathrm{C}$.

The occurrence and thickness of Jurassic magmatism is not uniform throughout the TAM (e.g., Elliot and Fleming, 2004), with inferred areas of intense activity and regions where activity was much less. Thus, it's difficult to gauge the potential thermal effect of Jurassic magmatism on our samples based on proximity to sills as none exist in the Thiel Mountains. The stratigraphy of Beacon Supergroup strata in the Thiel Mountain region is also poorly constrained making it difficult to estimate the possible depth of burial (and hence erosion) of the presumed Kukri Peneplain surface (and our samples).

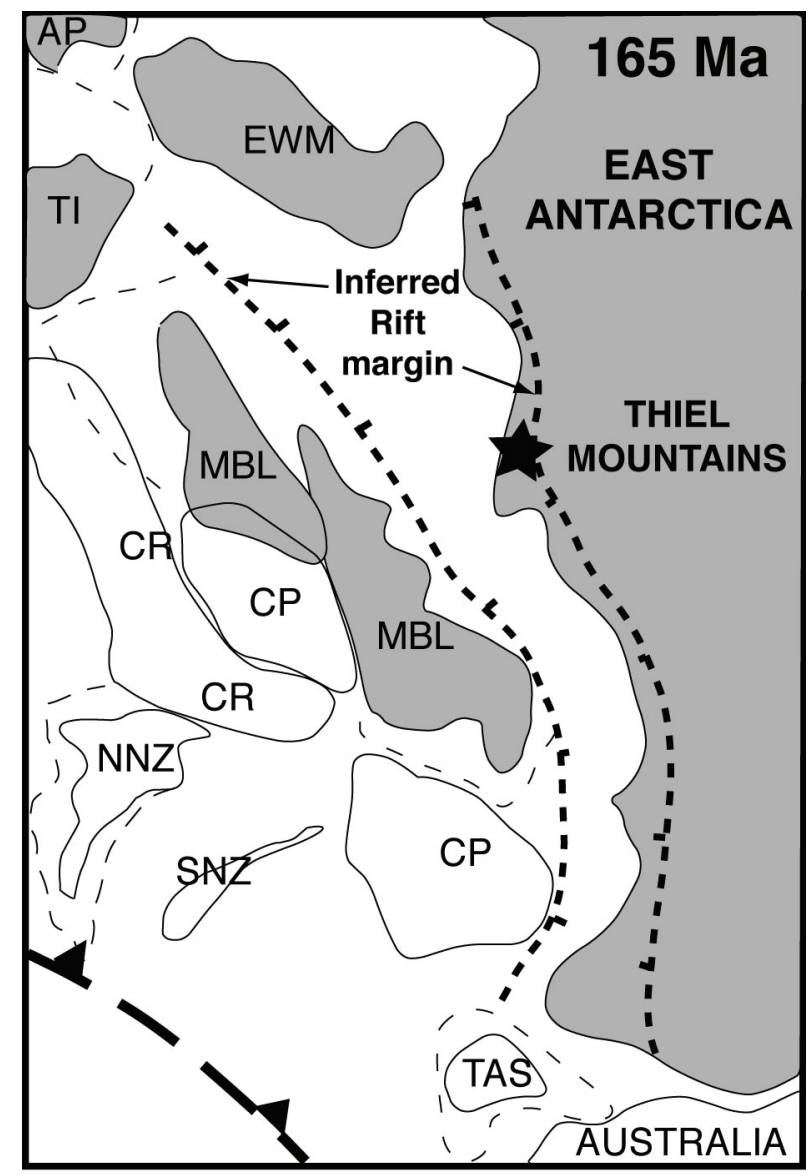

Figure 5. Reconstruction at $165 \mathrm{Ma}$ showing the inferred outline of the Jurassic rift (modified from Elliot, 1992 with plate configuration from Lawver et al., 1999). $\mathrm{AP}=$ Antarctic Peninsula, EWM=Ellsworth Whitmore crustal block, $\mathrm{TI}=$ Thurston Island, $\mathrm{MBL}=$ Marie Byrd Land, CR-Chatham Rise, $\mathrm{CP}=$ Campbell Plateau, TAS=Tasmania, NNZ/SNZ=north/south New Zealand.

Taking into account that magmatism occurred 15 m.y. prior to cooling, that there is no reported field evidence for Jurassic magmatism in the Thiel Mountains, and that there is no apparent partial loss of ${ }^{40} \mathrm{Ar}$ revealed in the $\mathrm{K}$ feldspar ${ }^{40} \mathrm{Ar} /{ }^{39} \mathrm{Ar}$ data, our interpretation of the cooling revealed in AFT data is that it was due to erosional denudation. The most likely cause of denudation was 
creation of relief (a rift-flank) associated with the Jurassic Transantarctic volcano-tectonic rift system (e.g., Elliot, 1992; Wilson, 1993). The region between East and West Antarctica has long since been inferred to be a rift zone associated with the early stages of Gondwana break-up and intimately associated with tholeiitic magmatism (e.g., Elliot and Fleming, 2004). The boundary faults to this Jurassic rift system are not known, although it has been suggested they may be hidden under the East Antarctic Ice Sheet or Ross Embayment (Elliot and Fleming, 2004). Analyses of dyke orientations along the TAM indicate extension perpendicular to the TAM and that crustal extension occurred prior to and during Ferrar magmatism (Wilson, 1993). The slope of a best-fit line to the AFT data is $60 \pm 37 \mathrm{~m} / \mathrm{m} . \mathrm{y}$. $(1 \sigma)$ indicating that the rate of denudation is actually very slow, and thus if denudation did not begin until $\sim 165 \mathrm{Ma}$, then that may reflect rift escarpment retreat or down-wearing from a rift flank outboard of the Thiel Mountains. As mentioned above, these results do not preclude other denudation episodes in the Thiel Mountains, either in the Cretaceous or Cenozoic, although all denudation events combined will not exceed ca. $4 \mathrm{~km}$. Any Cretaceous or Cenozoic denudation events are likely to be much less significant than in other parts of the TAM because the Thiel Mountains are further from the present West Antarctic rift system. Jurassic denudation in the Thiel Mountains is the oldest episode of denudation associated with the formation of the present-day TAM.

\section{Conclusions}

AFT data combined with thermal models from samples spanning $600 \mathrm{~m}$ relief on the north flank of the Thiel Mountains indicate cooling from ca. 165 to $150 \mathrm{Ma}$. There is no evidence for Jurassic magmatism in the Thiel Mountains, nor does a ${ }^{40} \mathrm{Ar} /{ }^{39} \mathrm{Ar}$ age spectra on $\mathrm{K}$-feldspar indicate any apparent partial loss of ${ }^{40} \mathrm{Ar}$ during the Jurassic. Thus, cooling was due to erosional denudation and not thermal relaxation following the Ferrar magmatism that occurred during a very short interval at $180 \mathrm{Ma}$. We interpret the slope of the AFT-elevation plot to indicate denudation at a rate of $\sim 65 \mathrm{~m} / \mathrm{m}$.y. from $\sim 165-$ $150 \mathrm{Ma}$. The cause of this denudation we attribute to the formation of relief associated with Transantarctic rifting in the Jurassic. This is the oldest denudation episode related to the formation of the present-day TAM. This event is revealed in the Thiel Mountains due to their distal location with respect to the West Antarctic rift system.

Acknowledgements. This work was funded by the National Science Foundation grant OPP-9615294. Charlie and Mary Hobbs are thanked for assistance in the field. Thanks to Paul O'Sullivan for analyzing 3 fission track samples, Erika Schwabe for determining Dpar on all samples, and Laura Webb for running sample $\mathrm{TH}-7$ for ${ }^{40} \mathrm{Ar} /{ }^{39} \mathrm{Ar}$ analysis in the Syracuse University Noble Gas Isotope Research Laboratory (SUNGIRL). Reviews by David Elliot and an anonymous reviewer helped improve this manuscript. We also thank co-editor Bryan Storey.

\section{References}

Craddock, C. (1983), The East Antarctica - West Antarctica boundary between the ice shelves: A review, in Antarctic Earth Science, edited by R. L. Oliver, et al., 94-97, Aust. Academy Sci., Canberra.

Dalziel, I. W. D. (1992), Antarctica: A tale of two supercontinents, Annual Review of Earth and Planetary Sciences, 20, 501-526.

Elliot, D. H. (1992), Jurassic magmatism and tectonism associated with Gondwanaland break-up; an Antarctic perspective, in Magmatism and the causes of continental break-up., edited by B. C. Storey, et al., 165184, Geol. Soc. London.

Elliot, D. H., and T. H. Fleming (2004), Occurrence and dispersal of magmas in the Jurassic Ferrar large igneous province, Antarctica, Gondwana Research, 7, 223-237.

Encarnación, J., T. H. Fleming, D. H. Elliot, and H. V. Eales (1996), Synchronous emplacement of Ferrar and Karoo dolerites and the early breakup of Gondwana, Geology, 24, 535-538.

Fitzgerald, P. G. (2002), Tectonics and landscape evolution of the Antarctic plate since Gondwana breakup, with an emphasis on the West Antarctic rift system and the Transantarctic Mountains, in Antarctica at the close of a Millennium. Proceedings of the 8th International Symposium on Antarctic Earth Science, edited by J. A. Gamble, et al., 453-469, Royal Society of New Zealand.

Fitzgerald, P. G., S. L. Baldwin, P. B. O'Sullivan, and L. E. Webb (2006), Interpretation of (U-Th)/He single grain ages from slowly cooled crustal terranes: A case study from the Transantarctic Mountains of southern Victoria Land, Chem. Geol., 225, 91-120.

Fitzgerald, P. G., and A. J. W. Gleadow (1990), New approaches in fission track geochronology as a tectonic tool: Examples from the Transantarctic Mountains, Nucl. Tracks, 17, 351-357.

Fleming, T. H., A. Heimann, K. A. Foland, and D. H. Elliot (1997), ${ }^{40} \mathrm{Ar}{ }^{39} \mathrm{Ar}$ geochronology of Ferrar Dolerite sills from the Transantarctic Mountains, Antarctica: Implications for the age and origin of the Ferrar magmatic province, Geol. Soc. Am. Bull., 109, 533-546.

Ford, A. B., and J. M. Aaron (1962), Bedrock geology of the Thiel Mountains, Antarctica, Science, 137, 751-752.

Ketcham, R. A., R. A. Donelick, and M. B. Donelick (2000), AFTSolve: A program for multi-kinetic modeling of apatite fission-track data, Geological Materials Research, 2, 1-32.

Lawver, L. A., I. W. D. Dalziel, and L. Gahagan (1999), Antarctica: Keystone of Gondwana (powerpoint presentation), http://www.ig.utexas.edu/research/projects/plates.

Pankhurst, R. J., B. C. Storey, I. L. Millar, D. I. M. Macdonald, and W. R. Vennum (1988), Cambrian-Ordovician magmatism in the Thiel Mountains, Transantarctic Mountains, and implications for the Beardmore Orogeny, Geology, 16, 246-249.

Storey, B. C., and I. D. Dalziel (1987), Outline of the structural and tectonic history of the Ellsworth Mountains-Thiel Mountains ridge, West Antarctica, 117-128 pp., Am. Geophys. Un.. Monograph.

Van Schmus, W. R., L. W. McKenna, D. A. Gonzales, A. H. Fetter, and A. J. Rowell (1997), U-Pb geochronology of parts of the Pensacola, Thiel, and Queen Maud Mountains, Antarctica, in The Antarctic Region: Geologial Evolution and Processes, edited by C. A. Ricci, 187-200, Terra Antartica Publication, Siena.

Wilson, T. J. (1993), Jurassic faulting and magmatism in the Transantarctic Mountains: Implications for Gondwana breakup, in Gondwana 8 - Assemby, Evolution, and Dispersal, edited by R. H. Findlay, et al., 563-572, A.A. Balkema, Rotterdam, Netherlands. 